\title{
EFEKTIVITAS EKSTRAK DAUN GEDI MERAH TERHADAP GLUKOSA DARAH, MALONDIALDEHID, 8-HDROKSI-DEOKSIGUANOSIN, INSULIN TIKUS DIABETES
}

\author{
Joni Tandi ${ }^{1}$, Muthi'ah $\mathrm{HZ} \mathrm{Z}^{1}$, Yuliet $^{2}$, Yusriadi ${ }^{2}$ \\ ${ }^{1}$ Program Studi Farmasi Sekolah Tinggi Ilmu Farmasi Pelita Mas, Palu, Sulawesi Tengah \\ ${ }^{2}$ Fakultas MIPA Jurusan Farmasi Universitas Tadulako, Palu, Sulawesi Tengah \\ *Email : jonitandi757@yahoo.com
}

\begin{abstract}
Red Gedi Leaves Extract (RGLE) have phytochemicals such as alkaloids, flavonoids, polyphenols, saponins and tannins which known as antidiabetic agents. Study had been done about RGLE (Abelmoschus manihot (L.) Medic) on blood glucose level, 8-hydroxydeoksiguanosin, malondialdehyde and insulin in diabetic rats (Rattus norvegicus). This study aims to prove the effects of RGLE in blood glucose levels, 8-hydroxy-deoksiguanosin, and malondialdehyde and insulin levels in rats with diabetes induced by streptozotocin and which is the most effective dosage of RGLE. Study used pre and post test design. RGLE obtained by maceration method using by ethanol $96 \%$. There were 120 white male rats which were divided into six treatment groups, each group consisting of 20 individuals. Group I (healthy control), II (negative control) were given by Na-CMC $0.5 \%$. Group III as the positive control were given by glibenclamide, group IV, V, and VI given by RGLE with different doses $(150,300$ and 450$) \mathrm{mg} / \mathrm{kg} \mathrm{BW}$. Animal test were diabetic induced by Streptozotocin with $40 \mathrm{mg} / \mathrm{kg} \mathrm{BW}$ dosage i.p. Data were analyzed by One Way (ANOVA). The result showed that RGLE can reduced blood glucose levels, 8-hydroxy-deoksiguanosin, and malondialdehyde and increased insulin levels in diabetic rats. The Effective Dosage of RGLE is $150 \mathrm{mg} / \mathrm{kg} \mathrm{BW}$.
\end{abstract}

Keywords : RGLE(Red Gedi Leaves Extract),Glukose,8-hidroksideoksiguanosin, Malondialdehyde, Insulin.

\begin{abstract}
ABSTRAK
EDGM (Ekstrak Daun Gedi Merah) mengandung alkaloid, flavonoid, polifenol, saponin, dan tanin diduga mempunyai efek antidiabetes. Telah dilakukan penelitian dari EDGM (Abelmoschus manihot (L.) Medik) terhadap kadar glukosa darah (KGD), 8-hidroksideoksiguanosin, malondialdehid, insulin pada tikus putih (Rattus norvegicus) diabetes yang diinduksi streptozotocin telah dilakukan. Tujuan penelitian ini untuk membuktikan kemampuan EDGM terhadap KGD, 8-hidroksi-deoksiguanosin, dan malondialdehid, insulin pada tikus putih diabetes diinduksi streptozotocin dan menentukan dosis paling efektif. Rancangan penelitian digunakan adalah pre and post test design. EDGM diperoleh dengan cara metode etanol 96\%. Penelitian ini menggunakan hewan uji tikus putih jantan sebanyak 120 ekor yang dibagi menjadi 6 kelompok perlakuan, tiap kelompok terdiri dari 20 ekor. Kelompok kontrol I (sehat), II negatif(-) diberikan suspensi Na-CMC 0,5\%, III positif(+)
\end{abstract}


diberikan suspensi glibenklamid, kelompok IV, V, dan VI diberikan EDGM masing-masing dengan dosis 150, 300 dan $450 \mathrm{mg} / \mathrm{kgBB}$. Model hewan uji diabetes dibuat dengan cara induksi streptozotocin dengan dosis $40 \mathrm{mg} / \mathrm{kgBB}$ secara intraperitoneal. Data yang diperoleh dianalisis menggunakan uji statistik one way (ANOVA) pada taraf kepercayaan $95 \%$. Berdasarkan hasil penelitian menunjukkan bahwa ekstrak daun gedi merah dapat menurunkan KGD, 8-hidroksi-deoksiguanosin, malondialdehid dan meningkatkan kadar insulin pada tikus putih diabetes yang diinduksi streptozotocin. Dosis EDGM yang efektif yaitu dosis $150 \mathrm{mg} / \mathrm{kg} \mathrm{BB}$.

Kata Kunci: EDGM(Ekstrak DaunGediMerah),Glukosa Darah,8-Hidroksideoksiguanosin, Malondialdehid, insulin.

\section{PENDAHULUAN}

Perubahan pola makan seharihari menjadi salah satu faktor pemicu perkembangan penyakit degeneratif. Makanan cepat saji (fast food) menjadi salah satu tipe makanan yang banyak dikonsumsi masyarakat saat ini, tak terkecuali masyarakat di Indonesia. Perkembangan penyakit diabetes melitus di Indonesia yang meningkat dari tahun ke tahun diduga berkaitan dengan kebiasaan pola makan masyarakat Indonesia yang telah berubah. ${ }^{(1)}$

Diabetes Melitus menurut World Health Organization (WHO) adalah kondisi kronis yang terjadi ketika kadar glukosa darah berada di atas normal akibat pankreas tidak cukup memproduksi insulin atau tidak efektifnya tubuh dalam menggunakan insulin yang diproduksi. ${ }^{(2)}$ Insulin memainkan peranan penting dalam keseimbangan energi. Insulin meningkatkan penyimpanan energi melalui stimulasi sintesis glikogen dan menstimulasi ambilan glukosa pada otot dan lemak, serta menstimulasi penyimpanan lemak melalui stimulasi lipoprotein lipase. ${ }^{(3)}$ Peningkatan kadar glukosa darah atau hiperglikemia yang terjadi pada DM menyebabkan autooksidasi glukosa, glikasi protein, dan aktivasi jalur metabolisme poliol yang selanjutnya mempercepat pembentukan senyawa oksigen reaktif. Senyawa oksigen reaktif adalah radikal bebas yang mengandung oksigen. Oksigen mengandung radikal bebas seperti radikal hydroxyl, radikal superoxide anion, radikal hydrogen peroxide, oxygen tunggal, radikal nitric oxide dan peroxynitrite yang merupakan spesies reaktif tinggi pada nukleus dan membran sel. Pembentukan senyawa oksigen reaktif tersebut dapat meningkatkan modifikasi lipid, DNA, dan protein pada berbagai jaringan. ${ }^{(4)}$ Senyawa oksigen reaktif yang berinteraksi dengan lipid bilayer pada membran sel akan menghasilkan peroksidase lipid dan akan membentuk produk akhir yang stabil berupa malondialdehyde (MDA). ${ }^{(5)}$ Reaksi penyerangan spesies reaktif pada molekul DNA akan menyebabkan terjadinya modifikasi atau kerusakan pada struktur DNA dan mempengaruhi informasi genetik yang terkandung di dalamnya. Salah satu parameter biologik yang dapat digunakan dalam identifikasi kerusakan DNA adalah 8-Hidroksideoksiguanosin $(8-\mathrm{OHdG}) .{ }^{(6)}$

Mekanisme

pertahanan antioksidan secara normal tidak cukup untuk menangkal kerusakan akibat radikal bebas, sehingga pemberian antioksidan eksogen yang berasal dari bahan alam memiliki peran menjanjikan untuk dapat menangkal radikal bebas yang meningkat di dalam tubuh. Beberapa antioksidan yang berasal dari bahan alami telah terbukti dan banyak digunakan sebagai agen penangkal terhadap stres oksidatif pada berbagai jenis penyakit. ${ }^{(7)}$

Salah satunya adalah Tanaman Gedi (Abelmoschus manihot L. Medik) 
yang merupakan tumbuhan tropis famili Malvaceae, secara tradisional telah lama dikenal di Sulawesi Utara sebagai tanaman sayuran. Berbagai jenis sayuran berkhasiat obat karena mengandung senyawa kimia tertentu. Senyawa kimia ini mempunyai efek farmakologis untuk membantu penyembuhan berbagai jenis penyakit. ${ }^{(8)}$ Tanaman gedi mengandung quercetin-3-o-robinobiosid, hyperin, isoquercetin, gossipetin-8-o-glukuronid, dan myricetin. ${ }^{(9)}$ Berdasarkan penelitian Mandey (2013) diketahui bahwa daun gedi merah mengandung flavonoid, alkaloid, saponin, steroid, dan juga mengandung protein tinggi, serat, dan kalsium. ${ }^{(10)}$ Masyarakat di Sulawesi Utara memanfaatkan daun gedi yang direbus tanpa garam sebagai obat tradisional, antara lain untuk sakit ginjal, maag, dan kolesterol tinggi. ${ }^{(11)}$ Senyawa hyperin yang terkandung dalam gedi merah memiliki kemampuan antivirus, antinosiseptif, antiinflamasi, kardioprotektif, hepatoprotektif, dan efek protektif terhadap terhadap gastrimukosal (lapisan membran mukus pada lambung). ${ }^{(12)}$ Sarwar et al (2011) menyatakan bahwa gedi memiliki efek antiinflamasi dan antidiabetes yang kuat. ${ }^{(13)}$

Tujuan penelitian ini adalah untuk membuktikan efek EDGM dalam menurunkan kadar glukosa darah, MDA, 8-OHdG, dan meningkatkan kadar insulin serta untuk menentukan dosis EDGM yang efektif untuk menurunkan kadar glukosa darah, MDA, 8-OHdG, dan meningkatkan kadar insulin pada tikus putih diabetes yang diinduksi Streptozotocin.

\section{METODE PENELITIAN}

\section{Bahan}

Aluminium Foil, Aqua Destillata, Aqua Pro Injeksi, Biotinylated Detection Ab Diluent (Elabscience), Concentrated Biotinylated Detection Ab
(Elabscience), Concentrated Horseradish Peroxidase (HRP) Conjugate (Elabscience), Concentrated Wash Buffer (25x) (Elabscience), Daun Gedi Merah (Abelmoschus manihot (L.) Medik), Etanol 96\%, Eter, Glibenklamid, $\mathrm{HCl}$, HRP Conjugate Diluent (Elabscience), Kertas saring, Na-CMC, Pereaksi Dragendorf, Pereaksi $\mathrm{FeCl}_{3}$, Plate Sealer, Reference Standard (Elabscience), Reference Standard \& Sample Diluent (Elabscience), Stik Glukometer, Stop Solution (Elabscience), Streptozotocin(STZ), Substrate Reagent (Elabscience).

\section{Peralatan}

Alat-alat Gelas Laboratorium, Batang Pengaduk, Blender, Glukometer (Nesco), Inkubator, Kandang Hewan Uji, Micro Elisa Plate, Pipet Eppendorf (Socorex), Rak Tabung, Rotavapor, Sendok Tanduk, Sentrifuge, Spektrofotometer Microplate Reader (Bio-Rad), Spoit Injeksi, Spoit Oral, Stopwatch, Tabung Reaksi, Timbangan Analitik, Timbangan Digital, Wadah Maserasi, Water Bath.

\section{Prosedur}

Prosedur penelitian dirangkai menjadi suatu prosedur penelitian yang utuh, mulai dari perencanaan atau persiapan tindakan yang dilakukan dalam rangka pelaksanaan penelitian adalah sebagai berikut:

\section{Pengambilan dan Pengolahan Bahan Uji. \\ Pembuatan EDGM. \\ Pembuatan Suspensi Na-CMC $0,5 \%$. \\ Pembuatan Suspensi Glibenklamid. \\ Pembuatan Suspensi STZ.}




\section{Pembuatan Dosis Sampel Uji $\rightarrow$ Pemilihan dan penyiapan Hewan Uji.}

\section{Pengujian Terhadap EDGM}

Setelah diadaptasikan, pada hari ke-0 tikus diambil secara acak dan dibagi ke dalam 6 kelompok. Kemudian pada hari ke-1, tikus dipuasakan selama 16 jam, dilanjutkan pengambilan darah tikus melalui ekor untuk mengetahui KGD dan melalui vena jantung untuk mengetahui kadar MDA, kadar 8-OHdG dan kadar insulin awal sebelum diinduksi STZ. Kemudian semua tikus diinduksi STZ dengan dosis $40 \mathrm{mg} / \mathrm{kg}$ BB secara intraperitonial kecuali pada kelompok kontrol normal/sehat. Hari ke-7 setelah induksi, tikus dipuasakan selama 16 jam kemudian dilanjutkan pengambilan darah tikus melalui vena ekor untuk mengetahui kadar glukosa darah dan melalui vena jantung untuk mengetahui kadar MDA, 8OHdG, dan insulin setelah induksi STZ. Setelah mencapai kadar hiperglikemia di atas $200 \mathrm{mg} / \mathrm{dL}$ untuk kadar glukosa darah, tikus diberikan perlakuan berdasarkan masing-masing kelompok sebagai berikut : Kelompok I kontrol sehat dan kelompok II kontrol (-) diberikan suspensi Na-CMC 0,5\%, kelompok III sebagai kontrol (+) diberikan suspensi glibenklamid, kelompok IV, V, dan VI diberikan EDGM masing-masing dengan dosis $150 \mathrm{mg} / \mathrm{kg} \mathrm{BB}, 300 \mathrm{mg} / \mathrm{kg} \mathrm{BB}$, dan $450 \mathrm{mg} / \mathrm{kg} \mathrm{BB}$. Kemudian pada hari ke14, ke-21, dan ke-28, tikus dipuasakan selama 16 jam (tetap diberi minum) kemudian mengukur kembali KGD, MDA, 8-OHdG, dan insulin setelah perlakuan pada tikus dan mencatat semua data yang diperoleh.

\section{Pengukuran Kadar Glukosa Darah (KGD)}

Sebelum diukur, tikus dipuasakan selama 16 jam. Darah diambil melalui ujung ekor tikus yang sebelumnya dibersihkan dengan alkohol 70\%, kemudian diurut perlahan-lahan, darah yang keluar kemudian diteteskan pada stik glukometer, dalam waktu 10 detik kadar glukosa darah akan terukur secara otomatis dan hasilnya dapat dibaca pada monitor glukometer. Semua tikus diukur KGD untuk memastikan semua tikus memiliki KGD normal sebelum diberi perlakuan. KGD puasa normal pada tikus berkisar antara 50-135 mg/dl.

\section{Pengukuran Kadar MDA, 8-OHdG, dan Insulin}

Pengukuran kadar MDA, 8OHdG, dan Insulin dilakukan dengan menggunakan ELISA kit.

\section{Analisis data \\ Data yang diperoleh pada} penelitian ini, dirancang menggunakan metode pre and post test only design dan dianalisis dengan uji One Way Anova untuk mengetahui adanya perbedaan antar kelompok pada taraf signifikan $95 \%$. Apabila uji One Way Anova menunjukkan perbedaan yang bermakna maka dilanjutkan dengan uji lanjut Post Hoc Duncan untuk mengetahui kelompok perlakuan yang berbeda signifikan dibandingkan kelompok perlakuan lainnya. Pengolahan data dilakukan menggunakan program Software SPSS 16.0.

\section{HASIL DAN PEMBAHASAN}

\section{Hasil Uji Penapisan Fitokimia}

Uji penapisan fitokimia dilakukan untuk mengetahui golongan senyawa metabolit sekunder yang terdapat pada EDGM. Hasil uji penapisan fitokimia dapat dilihat pada Tabel 1 .

Profil KGD, MDA, 8-OhdG, dan Insulin darah tikus putih sebelum perlakuan, setelah induksi STZ dan setelah pemberian EDGM selama 28 hari berikut berturut-turut (Gambar 1, 2, 3, 4). 
Tabel 1. Hasil uji penapisan fitokimia EGDM (Abelmoschus manihot (L.) Medik)

\begin{tabular}{ccccc}
\hline No & Kandungan kimia & Pereaksi & Hasil pengamatan & Ket. \\
\hline 1 & Alkaloid & Dragendorff & Merah Jingga & $(+)$ \\
2 & Flavonoid & Serbuk $\mathrm{Mg}+\mathrm{HCl}$ & Kuning Jingga & $(+)$ \\
3 & Saponin & $\mathrm{HCl}$ & Terbentuk Busa & $(+)$ \\
4 & Tanin & $\mathrm{FeCl} 3$ & Biru Hitam & $(+)$ \\
5 & Polifenol & $\mathrm{FeCl} 3$ & Biru Hijau & $(+)$ \\
\hline
\end{tabular}

Keterangan : $(+)=$ Mengandung senyawa yang diuji

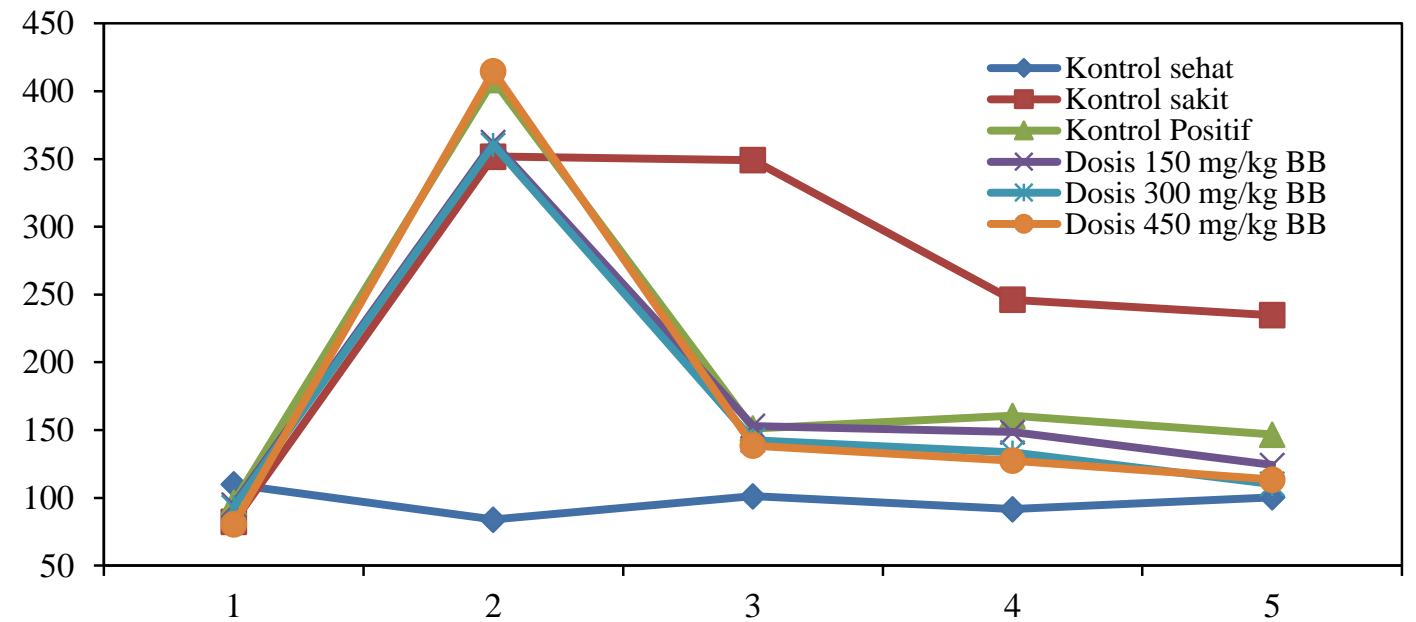

Gambar 1. Grafik KGD tikus putih sebelum perlakuan, setelah diinduksi dengan STZ dan setelah pemberian EDGM

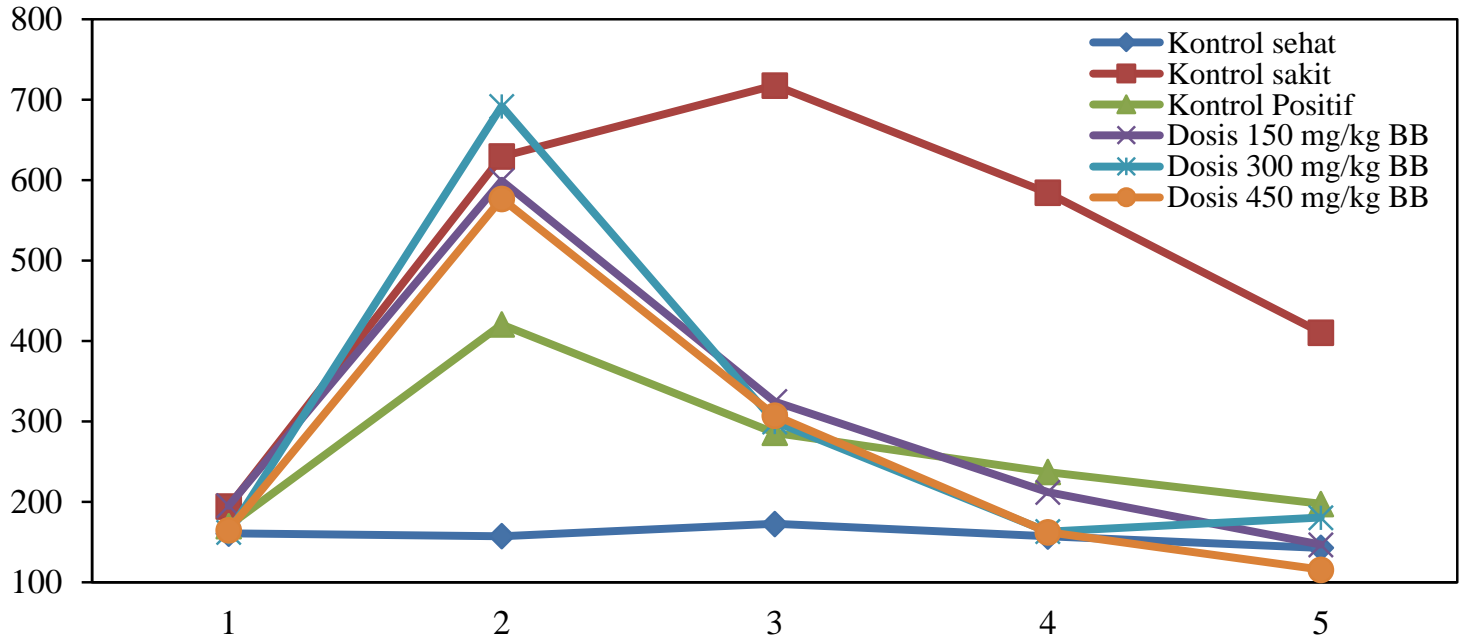

Gambar 2. Grafik kadar MDA tikus putih sebelum perlakuan, setelah diinduksi dengan STZ dan setelah pemberian EDGM 


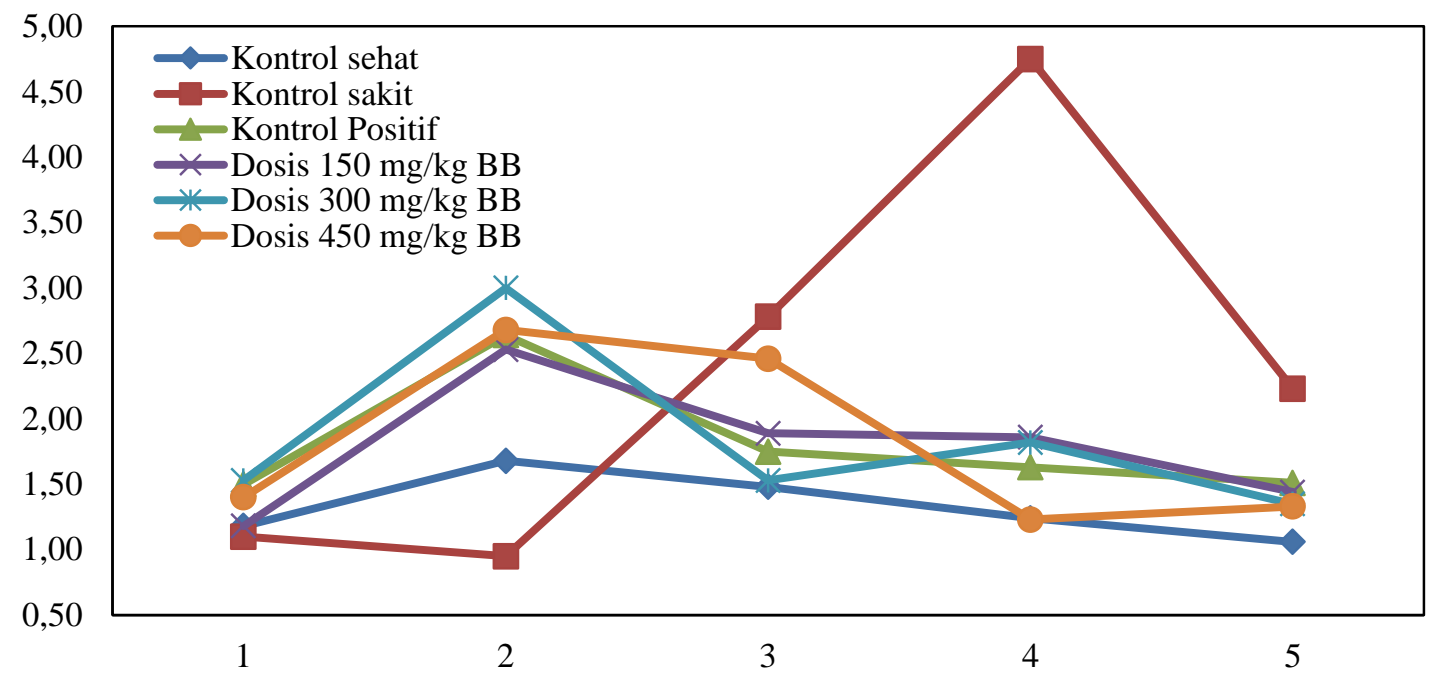

Gambar 3. Grafik kadar 8-OHdG tikus putih sebelum perlakuan, setelah diinduksi dengan STZ dan setelah pemberian EDGM

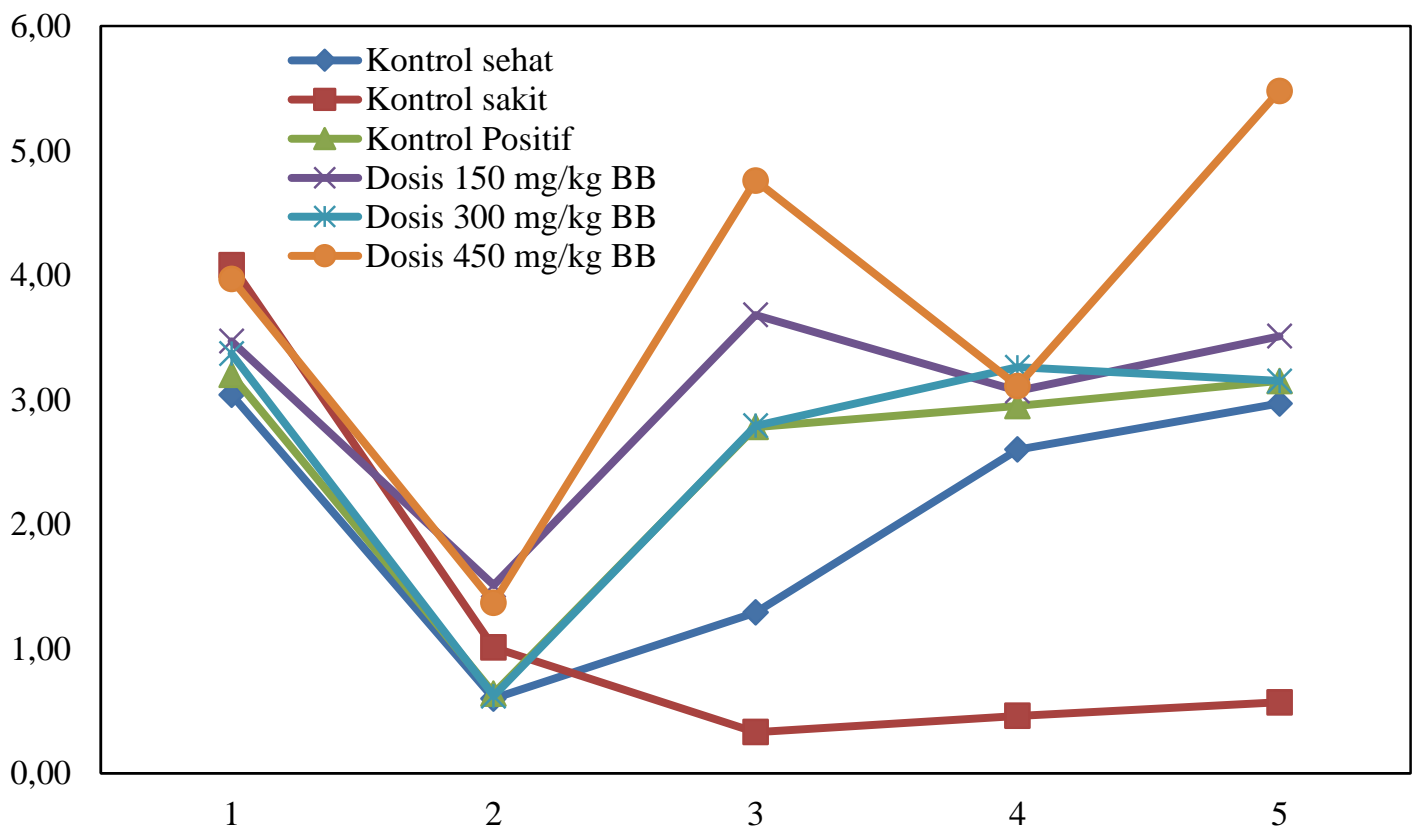

Gambar 4. Grafik kadar insulin tikus putih sebelum perlakuan, setelah diinduksi dengan STZ dan setelah pemberian EDGM

\section{Hasil Analisis Uji One Way Anova}

Analisis uji One Way Anova dilakukan dengan menggunakan program SPSS untuk mengetahui adanya perbedaan antara kontrol (-), kontrol (+) glibenklamid, dan kelompok EDGM pada hari ke-14, ke-21, dan ke-28. Apabila uji One Way Anova menunjukkan perbedaan yang bermakna maka dilanjutkan dengan uji lanjut Post Hoc Duncan. Hasil tersebut dapat dilihat pada Tabel 6, 7, 8, dan 9. 
Tabel 6. Rerata selisih penurunan kadar glukosa darah hari ke-14, ke-21, dan ke-28

\begin{tabular}{cccc}
\hline \multirow{2}{*}{ Kelompok Perlakuan } & \multicolumn{3}{c}{ Selisih Penurunan KGD (mg/dL) } \\
\cline { 2 - 4 } & Hari ke-14 & Hari ke-21 & Hari ke-28 \\
\hline Kontrol (-) & $2,5 \pm 60,00^{\mathrm{a}}$ & $105,5 \pm 51,60^{\mathrm{a}}$ & $117 \pm 100,25^{\mathrm{a}}$ \\
Kontrol (+) & $257 \pm 62,52^{\mathrm{b}}$ & $247,75 \pm 28,53^{\mathrm{b}}$ & $261,25 \pm 41,62^{\mathrm{b}}$ \\
EDGM 150 mg/kg BB & $209,5 \pm 43,64^{\mathrm{b}}$ & $214 \pm 45,26^{\mathrm{b}}$ & $238,25 \pm 24,93^{\mathrm{b}}$ \\
EDGM 300 mg/kg BB & $218 \pm 54,10^{\mathrm{b}}$ & $227 \pm 50,60^{\mathrm{b}}$ & $250,25 \pm 56,84^{\mathrm{b}}$ \\
EDGM 450 mg/kg BB & $276,25 \pm 45,48^{\mathrm{b}}$ & $284,75 \pm 52,99^{\mathrm{b}}$ & $301,25 \pm 43,02^{\mathrm{b}}$ \\
\hline
\end{tabular}

Ket: Abjad yang sama menunjukkan perbedaan yang tidak signifikan

Abjad yang berbeda menunjukkan perbedaan yang signifikan

Tabel 7. Rerata selisih penurunan kadar MDA hari ke-14, ke-21, dan ke-28

\begin{tabular}{cccc}
\hline \multirow{2}{*}{ Kelompok } & \multicolumn{3}{c}{ Selisih Penurunan Kadar MDA (ng/mL) } \\
\cline { 2 - 4 } & Hari ke-14 & Hari ke-21 & Hari ke-28 \\
\hline Kontrol (-) & $-88,27 \pm 113,79^{\mathrm{a}}$ & $45,29 \pm 117,92^{\mathrm{a}}$ & $219,03 \pm 168,36^{\mathrm{a}}$ \\
Kontrol (+) & $134,59 \pm 87,11^{\mathrm{b}}$ & $183,33 \pm 84,85^{\mathrm{a}}$ & $223,01 \pm 79,22^{\mathrm{a}}$ \\
EDGM 150 mg/kg BB & $274,53 \pm 40,83^{\mathrm{bc}}$ & $387,33 \pm 26,68^{\mathrm{b}}$ & $452,62 \pm 23,23^{\mathrm{b}}$ \\
EDGM 300 mg/kg BB & $392,31 \pm 109,17^{\mathrm{c}}$ & $528,91 \pm 58,02^{\mathrm{b}}$ & $511,65 \pm 64,91^{\mathrm{b}}$ \\
EDGM 450 mg/kg BB & $269,51 \pm 220,23^{\mathrm{bc}}$ & $414,76 \pm 177,13^{\mathrm{b}}$ & $461,17 \pm 154,25^{\mathrm{b}}$ \\
\hline
\end{tabular}

Ket: Abjad yang sama menunjukkan perbedaan yang tidak signifikan

Abjad yang berbeda menunjukkan perbedaan yang signifikan

Tabel 8. Rerata selisih penurunan kadar 8-OHdG hari ke-14, ke-21, dan ke-28

\begin{tabular}{cccc}
\hline \multirow{2}{*}{ Kelompok } & \multicolumn{3}{c}{ Selisih Penurunan Kadar 8-OHdG (ng/mL) } \\
\cline { 2 - 4 } & Hari ke-14 & Hari ke-21 & Hari ke-28 \\
\hline Kontrol (-) & $-1,83 \pm 0,38^{\mathrm{a}}$ & $-3,80 \pm 1,36^{\mathrm{a}}$ & $-1,28 \pm 0,81^{\mathrm{a}}$ \\
Kontrol (+) & $0,89 \pm 0,71^{\mathrm{bc}}$ & $1,01 \pm 0,42^{\mathrm{b}}$ & $1,13 \pm 0,75^{\mathrm{b}}$ \\
EDGM 150 mg/kg BB & $0,64 \pm 0,60^{\mathrm{bc}}$ & $0,66 \pm 0,76^{\mathrm{b}}$ & $1,09 \pm 0,59^{\mathrm{b}}$ \\
EDGM 300 mg/kg BB & $1,48 \pm 0,65^{\mathrm{c}}$ & $1,18 \pm 0,94^{\mathrm{b}}$ & $1,65 \pm 0,87^{\mathrm{b}}$ \\
EDGM 450 mg/kg BB & $0,21 \pm 0,21^{\mathrm{b}}$ & $1,44 \pm 0,63^{\mathrm{b}}$ & $1,35 \pm 0,70^{\mathrm{b}}$ \\
\hline
\end{tabular}

Ket: Abjad yang sama menunjukkan perbedaan yang tidak signifikan Abjad yang berbeda menunjukkan perbedaan yang signifikan

Tabel 9. Rerata peningkatan kadar insulin hari ke-14, ke-21, dan ke-28

\begin{tabular}{cccc}
\hline \multirow{2}{*}{ Kelompok } & \multicolumn{3}{c}{ Selisih Penurunan Kadar insulin $(\mathrm{ng} / \mathrm{mL})$} \\
\cline { 2 - 4 } & Hari ke-14 & Hari ke-21 & Hari ke-28 \\
\hline Kontrol (-) & $-0,68 \pm 0,47^{\mathrm{a}}$ & $-0,55 \pm 0,41^{\mathrm{a}}$ & $-0,44 \pm 0,61^{\mathrm{a}}$ \\
Kontrol (+) & $2,15 \pm 0,73^{\mathrm{b}}$ & $2,31 \pm 0,43^{\mathrm{b}}$ & $2,52 \pm 0,21^{\mathrm{bc}}$ \\
EDGM 150 mg/kg BB & $2,17 \pm 2,63^{\mathrm{b}}$ & $1,56 \pm 0,92^{\mathrm{b}}$ & $2,00 \pm 2,01^{\mathrm{b}}$ \\
EDGM 300 mg/kg BB & $2,17 \pm 0,48^{\mathrm{b}}$ & $2,65 \pm 0,98^{\mathrm{b}}$ & $2,53 \pm 1,49^{\mathrm{bc}}$ \\
EDGM 450 mg/kg BB & $3,39 \pm 0,76^{\mathrm{b}}$ & $1,74 \pm 0,83^{\mathrm{b}}$ & $4,11 \pm 1,00^{\mathrm{c}}$ \\
\hline
\end{tabular}

Ket: Abjad yang sama menunjukkan perbedaan yang tidak signifikan

Abjad yang berbeda menunjukkan perbedaan yang signifikan 


\section{PEMBAHASAN}

Penelitian ini menggunakan daun gedi merah (Abelmoschus manihot (L.) Medik) yang diperoleh dari Kota Palu Sulawesi Tengah. Sebelumnya dilakukan determinasi tanaman di Pusat Penelitian Biologi-LIPI Bogor untuk memastikan jenis gedi yang digunakan. Hasilnya menunjukkan bahwa gedi yang digunakan dalam penelitian ini adalah benar spesies Abelmoschus manihot (L.) Medik. EGDM kental diperoleh dari proses maserasi. Maserasi adalah proses ekstraksi simplisia menggunakan pelarut dengan beberapa kali pengocokan pada temperatur ruangan. ${ }^{(14)}$ Metode maserasi dipilih karena adanya sifat daun yang lunak dan mudah mengembang dalam cairan pengekstraksi. Selain itu, maserasi merupakan cara penyarian yang sederhana karena cairan penyari akan menembus dinding sel dan masuk ke dalam rongga sel yang mengandung zat aktif. Zat aktif ini akan larut dan adanya perbedaan konsentrasi antara larutan zat aktif di dalam dengan di luar sel menyebabkan larutan yang terpekat keluar hingga terjadi keseimbangan konsentrasi antara larutan di dalam dengan di luar sel. Cairan penyari yang digunakan dalam proses maserasi ini adalah etanol 96\%. Etanol dipertimbangkan sebagai cairan penyari karena lebih selektif, kapang sulit tumbuh dalam etanol $20 \%$ ke atas, tidak beracun, netral, absorbsinya baik, etanol dapat bercampur dengan air dalam segala perbandingan, memerlukan panas yang lebih sedikit untuk proses pemekatan, dan zat pengganggu yang larut terbatas. Pelarut etanol dipilih sebagai cairan penyari karena senyawa yang akan diekstraksi adalah senyawa fenolik. ${ }^{(15,16)}$ Ekstrak kental yang diperoleh dari hasil maserasi simplisia daun gedi merah yaitu 52 gram dengan nilai rendemen yang diperoleh adalah 10,4\%.

Berdasarkan hasil uji fitokimia pada Tabel 1, dapat dikatakan bahwa
EDGM (Abelmoschus manihot (L.) Medik) mengandung senyawa-senyawa kimia yaitu alkaloid, flavonoid, saponin, tanin, dan polifenol. Hal ini sesuai dengan penelitian Mandey, 2013 yang menyatakan bahwa gedi merah (Abelmoschus manihot (L.) Medik) mengandung flavonoid, alkaloid, saponin. ${ }^{(17)}$

Penelitian ini menggunakan hewan uji berupa tikus putih jantan (Rattus norvegicus) sebanyak 120 ekor. Penggunaan tikus putih jantan sebagai hewan uji karena dapat memberikan hasil penelitian yang lebih stabil karena tidak dipengaruhi oleh siklus menstruasi dan kehamilan seperti pada tikus putih betina. Tikus putih jantan juga mempunyai kecepatan metabolisme obat yang lebih cepat dan kondisi biologis tubuh yang lebih stabil dibanding tikus betina. ${ }^{(18)}$ Sebelum digunakan, tikus terlebih dahulu diadaptasikan kurang lebih 2 minggu dengan tujuan agar tikus dapat beradaptasi dengan lingkungan barunya seperti kandang, makanan, minuman, suhu, dan kondisi sekitarnya. Setelah diadaptasikan tikus dikelompokkan menjadi 6 kelompok perlakuan yaitu kelompok kontrol sehat (tanpa induksi STZ maupun pemberian EDGM), kelompok kontrol (-) yang diinduksi STZ tanpa pemberian EDGM, kelompok kontrol (+) yang diberikan suspensi glibenklamid, kelompok perlakuan EDGM dosis 150, 300 dan 450 $\mathrm{mg} / \mathrm{kg}$ BB. Selanjutnya tikus dipuasakan selama 16 jam untuk menentukan KDG, MDA, 8-OHdG, dan insulin awal. Setelah itu, semua kelompok tikus diinduksi STZ dengan dosis $40 \mathrm{mg} / \mathrm{kg}$ BB i.p kecuali kelompok sehat. STZ sering digunakan sebagai induksi insulin-dependent dan non-insulin-dependent diabetes melitus pada hewan uji karena selektif merusak sel beta pankreas. STZ bekerja langsung pada sel beta pankreas dengan aksi sitotoksiknya dimediatori oleh reactive oxygen species (ROS) sehingga dapat digunakan sebagai induksi diabetes melitus. STZ sebagai agen diabetonik 
dapat memicu peningkatan produksi radikal bebas berlebih dan menyebabkan stress oksidatif. ${ }^{(19)}$ Kemudian mengukur KGD, MDA, 8-OHdG, dan insulin setelah induksi untuk melihat kenaikannya. Setelah itu, tikus diberi perlakuan sesuai kelompok yang telah ditentukan.

Berdasarkan hasil uji One Way Anova terhadap selisih penurunan KGD (Tabel 6) menunjukkan bahwa pada hari ke-14, ke-21, dan ke-28 diperoleh hasil terdapat perbedaan yang signifikan antara kontrol (-) dengan kontrol (+) dan ketiga variasi dosis EDGM. Hal ini dikarenakan kontrol (-) hanya diberikan suspensi NaCMC $0,5 \%$ yang tidak memiliki kandungan zat aktif dalam menurunkan KGD. Tetapi terdapat perbedaan yang tidak signifikan antara kontrol (+) dengan ketiga variasi dosis EDGM. Hal ini menunjukkan bahwa ketiga variasi dosis EDGM (Abelmoschus manihot (L.) Medik) mampu menurunkan KGD yang sebanding dengan kontrol (+).

Efek penurunan KGD

disebabkan adanya senyawa bioaktif yang terkandung dalam EDGM seperti alkaloid, flavonoid, saponin, polifenol, dan tanin. Alkaloid terbukti mempunyai kemampuan meregenerasi sel $\beta$ pankreas yang rusak. Adanya perbaikan pada jaringan pankreas, maka akan terjadi peningkatan jumlah insulin di dalam tubuh sehingga glukosa darah akan masuk ke dalam sel sehingga terjadi penurunan KGD dalam tubuh. ${ }^{(20)}$ Flavonoid pada EDGM dapat bersifat antioksidan. Flavonoid diketahui bertindak sebagai penangkal radikal hidroksi dan superhidroksi dengan demikian melindungi lipid membran sel $\beta$ pankreas terhadap reaksi yang merusak. ${ }^{(21)}$ Selain itu flavonoid juga diketahui dapat mengurangi peroksidasi lipid dan mengembalikan sensitivitas reseptor insulin pada sel. Kondisi tersebut menyebabkan penurunan kadar glukosa darah. ${ }^{(22)}$ Antioksidan pada polifenol mampu mengurangi stress oksidatif dengan cara mencegah terjadinya rantai pengubahan superoksida menjadi hidrogen superoksida dengan mendonorkan atom hidrogen dari kelompok aromatik hidkrosil (-OH) polifenol untuk mengikat radikal bebas dan membuangnya dari dalam tubuh melalui sistem ekskresi. ${ }^{(23)}$ Saponin bersifat adstringent yaitu menciutkan selaput lendir mukosa lambung sehingga menghambat penyerapan senyawa lainnya yang juga ikut berperan terhadap penurunan kadar glukosa darah yaitu alkaloid dan flavonoid. ${ }^{(24)}$ Selain itu senyawa saponin yang terdapat di dalam EDGM dapat menurunkan kadar glukosa darah dengan menghambat aktivitas enzim alfa glukosidase, yaitu enzim dalam pencernaan yang bertanggung jawab terhadap pengubahan karbohidrat menjadi glukosa. $^{(25)}$ Tanin diketahui dapat memacu metabolisme glukosa dan lemak sehingga timbunan kedua sumber kalori ini dalam darah dapat dihindar. Selain itu, tanin juga berfungsi sebagai astringent atau pengkhelat yang dapat mengerutkan membran epitel usus halus sehingga mengurangi penyerapan sari makanan dan sebagai akibatnya menghambat asupan glukosa dan laju peningkatan glukosa darah tidak terlalu tinggi. ${ }^{(25)}$

Hasil uji One Way Anova terhadap selisih penurunan kadar MDA (Tabel 7) menunjukkan bahwa pada hari ke-14 terdapat perbedaan yang signifikan antara kelompok kontrol (-) dengan kelompok kontrol $(+)$ dan ketiga variasi dosis EDGM. Hal ini dikarenakan kontrol (-) hanya diberikan suspensi Na-CMC $0,5 \%$ yang tidak memiliki kandungan zat aktif dalam menurunkan kadar MDA. Akan tetapi terdapat perbedaan yang tidak signifikan antara kelompok kontrol (+) dengan kelompok perlakuan EDGM dosis $150 \mathrm{mg} / \mathrm{kgBB}$ dan $450 \mathrm{mg} / \mathrm{kgBB}$. Hal ini menunjukkan bahwa kontrol (+) glibenklamid ikut berperan dalam menurunkan kadar MDA yang sebanding dengan EDGM dosis $150 \mathrm{mg} / \mathrm{kgBB}$ dan $450 \mathrm{mg} / \mathrm{kgBB}$. Hal ini bisa disebabkan karena glibenklamid mampu meningkatkan sekresi insulin sehingga 
KGD menurun dan secara tidak langsung mengurangi pembentukan senyawa oksigen reaktif akibat hiperglikemia. Namun terdapat perbedaan yang signifikan antara tiga dosis yang diujikan. Hasil menunjukkan bahwa EGDM dosis $300 \mathrm{mg} / \mathrm{kgBB}$ memiliki selisih penurunan kadar MDA yang paling tinggi. Hal ini bisa disebabkan karena dosis $300 \mathrm{mg} / \mathrm{kg}$ BB berada dalam konsentrasi terbaik untuk berikatan dengan reseptor sehingga reseptor dapat berikatan dengan obat dalam durasi yang lebih lama. Pada hari ke-21 dan ke-28 menunjukkan bahwa terdapat perbedaan yang tidak signifikan antara kelompok kontrol (-) dengan kelompok kontrol (+), namun terdapat perbedaan yang signifikan antara kontrol (+) dengan ketiga variasi dosis EDGM. Hal ini kemungkinan disebabkan karena kontrol (+) glibenklamid memiliki konsentrasi yang cukup untuk berikatan dengan reseptor, namun ikatan obatreseptor tersebut lemah sehingga pada durasi yang lebih lama ikatan obatreseptor mudah lepas sehingga pada akhirnya efek obat mulai berkurang.

Efek penurunan kadar MDA disebabkan adanya senyawa bioaktif yang terkandung dalam EDGM seperti flavonoid dan polifenol yang berperan sebagai antioksidan. Antioksidan sebagai senyawa yang dapat menunda, memperlambat, dan mencegah proses oksidasi lipid yang berperan dalam proses produksi MDA, sehingga dapat menurunkan kadar MDA. Kemampuan flavonoid sebagai antioksidan disebabkan karena flavonoid bertindak sebagai scavenger (pembersih) radikal bebas.

Hasil uji One Way Anova terhadap selisih penurunan kadar 8-OHdG (Tabel 8) menunjukkan bahwa pada hari ke-14 terdapat perbedaan yang signifikan antara kelompok control (-) dengan kelompok kontrol $(+)$ dan ketiga variasi dosis EDGM. Hal ini dikarenakan kontrol (-) hanya diberikan suspensi Na-CMC $0,5 \%$ yang tidak memiliki kandungan zat aktif dalam menurunkan kadar 8-OHdG.
Akan tetapi terdapat perbedaan yang tidak signifikan antara kelompok kontrol (+) dengan kelompok perlakuan EDGM dosis 150 dan $450 \mathrm{mg} / \mathrm{kgBB}$. Hal ini menunjukkan bahwa kontrol (+) glibenklamid ikut berperan dalam menurunkan kadar 8-OHdG yang sebanding dengan EDGM dosis 150 dan $450 \mathrm{mg} / \mathrm{kgBB}$. Hal ini dikarenakan glibenklamid mampu meningkatkan sekresi insulin sehingga kadar glukosa dalam darah menurun dan secara tidak langsung mengurangi pembentukan senyawa oksigen reaktif yang ikut berperan dalam merusak DNA sel beta pankreas. Namun terdapat perbedaan yang signifikan antara dosis 300, 150, 450 $\mathrm{mg} / \mathrm{kgBB}$. Hal ini menunjukkan bahwa EDGM dosis $300 \mathrm{mg} / \mathrm{kgBB}$ memiliki selisih penurunan kadar $8-\mathrm{OHdG}$ yang paling tinggi. Hal ini bisa disebabkan karena dosis $300 \mathrm{mg} / \mathrm{kg} \mathrm{BB}$ berada dalam konsentrasi terbaik untuk berikatan dengan reseptor sehingga reseptor dapat berikatan dengan obat dalam durasi yang lebih lama. Pada hari ke-21 dan ke-28 menunjukkan bahwa terdapat perbedaan yang tidak signifikan antara kelompok kontrol (+) dengan ketiga variasi dosis EDGM. Tetapi berbeda signifikan dengan kelompok kontrol (-) yang hanya diberikan suspensi Na-CMC 0,5\%.

Efek penurunan kadar $8-\mathrm{OHdG}$ disebabkan adanya senyawa bioaktif yang terkandung dalam EDGM seperti flavonoid dan polifenol yang berperan sebagai antioksidan. Antioksidan sebagai senyawa yang dapat menunda, memperlambat, dan mencegah kerusakan oksidatif DNA. Senyawa antioksidan ini menyerang ROS sebelum mereka menyebabkan kerusakan pada berbagai molekul biologis dan menghindarkan penyebaran kerusakan oksidatif dengan mengganggu reaksi rantai radikal bebas.

Hasil uji One Way Anova terhadap peningkatan kadar insulin (Tabel 9) menunjukkan bahwa pada hari ke-14 dan ke-21 terdapat perbedaan yang signifikan antara kelompok kontrol (-) 
dengan kelompok kontrol (+) dan ketiga variasi dosis EDGM. Hal ini dikarenakan kontrol (-) hanya diberikan suspensi NaCMC $0,5 \%$ yang tidak memiliki kandungan zat aktif yang ikut serta dalam meningkatkan kadar insulin. Akan tetapi terdapat perbedaan yang tidak signifikan antara kelompok kontrol (+) dengan ketiga variasi dosis EDGM. Hal ini disebabkan karena ketiga variasi dosis EDGM memiliki zat aktif yang mampu meningkatkan kadar insulin sebanding dengan kontrol (+). Pada hari ke-28 terdapat perbedaan yang signifikan antara kelompok kontrol (-) dengan kelompok kontrol (+) dan ketiga variasi dosis EDGM. Akan tetapi terdapat perbedaan yang tidak signifikan antara kelompok kontrol (+) dengan kelompok perlakuan EDGM dosis 150 dan $300 \mathrm{mg} / \mathrm{kgBB}$. Hal ini dikarenakan EDGM dosis 150 dan 300 $\mathrm{mg} / \mathrm{kgBB}$ memiliki efek yang sebanding dengan kontrol (+) glibenklamid dalam meningkatkan kadar insulin. Namun terdapat perbedaan yang signifikan antara ekstrak gedi merah dosis $450 \mathrm{mg} / \mathrm{kgBB}$ dengan EDGM dosis 150 dan 300 $\mathrm{mg} / \mathrm{kgBB}$. Hal ini menunjukkan bahwa EDGM dosis $450 \mathrm{mg} / \mathrm{kgBB}$ memiliki peningkatan kadar insulin yang paling tinggi. Hal ini bisa disebabkan karena dosis $450 \mathrm{mg} / \mathrm{kg}$ BB berada dalam konsentrasi terbaik untuk berikatan dengan reseptor sehingga reseptor dapat berikatan dengan obat dalam durasi yang lebih lama.

Efek peningkatan kadar insulin diduga terjadi karena senyawa aktif yang terkandung dalam EDGM seperti alkaloid, flavonoid dan polifenol. Alkaloid terbukti mempunyai kemampuan meregenerasi sel $\beta$-pankreas yang rusak. Adanya perbaikan pada jaringan pankreas, maka akan terjadi peningkatan jumlah insulin di dalam tubuh sehingga glukosa darah akan masuk ke dalam sel dan mengakibatkan penurunan KGD dalam tubuh. Flavonoid dan polifenol berperan sebagai antioksidan yang mampu mengurangi stres oksidatif dengan cara mencegah terjadinya rantai pengubahan superoksida menjadi hidrogen superoksida dengan mendonorkan atom hidrogen dari kelompok aromatik hidroksil (-OH) polifenol untuk mengikat radikal bebas dan membuangnya dari dalam tubuh melalui sistem ekskresi.

\section{KESIMPULAN}

Berdasarkan hasil penelitian efektivitas EDGM (Abelmoschus manihot (L.) Medik) terhadap KGD, MDA, 8OHdG, dan insulin pada tikus putih (Rattus norvegicus) yang diinduksi STZ dapat disimpulkan sebagai berikut :

1. EDGM (Abelmoschus manihot (L.) Medik) dapat menurunkan KGD, MDA, 8-OHdG serta meningkatkan kadar insulin tikus putih diabetes yang diinduksi STZ.

2. Dosis EDGM yang efektif adalah dosis $150 \mathrm{mg} / \mathrm{kg} \mathrm{BB}$.

\section{Saran}

Sebaiknya dilakukan penelitian lanjutan dengan melakukan pemeriksaan histopatologi terhadap jaringan pankreas untuk mengetahui perbaikan dalam meregenerasi sel beta pankreas.

\section{DAFTAR PUSTAKA}

1. Adji, Dirgo. 2008. Hubungan Konsentrasi Malondialdehid, Glukosa Dan Total Kolesterol Pada Tikus Putih Yang Diinjeksi Dengan Streptozotocin. Jurnal Sains, Vol. 26, No.2. Hal.74

2. World Health Organization (WHO). 2012. Diabetes Fact Sheet. Department of Sustainable Development and Healthy Environments.

3. Funk, J.L. and Feingold, K.R. 1995. Disorder of the Endocrine Pancrease. In: McPee, S.J., (Ed), A Lange Medical Book Pathophysiology of Disease an Introduction to Clinical Medicine, 1st ed. Stamford: Appleton \& Lange, p.367-392. 
4. Ueno $Y$, Kizaki M, Nakagiri R, Kamiya T, Sumi H, and Osawa T. 2002. Dietary gluthatione protects rats from diabetic nephropathy and neuropathy. J Nutr 32:897-900.

5. Mahreen R, Mohsin M and Nasreen Z. 2010. Significantly Increased Levels of Serum Malondialdehyde in Type 2 Diabetic with Myocardial Infarction. Int J Diab Ctries 30(1):49-51.

6. Utami, Vina. 2012. Studi Deteksi Senyawa 8-Hidroksi-'2Deoksiguanosin (8-OHdG) Sebagai Biomarker Genotoksisitas. [Skripsi]. Fakultas MIPA. Universitas Indonesia. Depok. Hal 6

7. Battacharya, S.K., Satyan, K.S., Ghosal, S., 1997. Antioxidant activity of glycowithanolides from Withania somnifera. Indian Journal of Experimental Biology 35: 236-239.

8. Kamiya, K., Saiki Y., Hama T., Fujimoto Y., Endang H., Umar M., and Satake, T. 2001. Flavonoi Glucuronides from Helicteres isora. Phytochemistry. 57:297-301.

9. Liu, Y., Xianyin L., Xiaomei L., Yuying Z., Jingrong C. 2006. Interactions Between Thrombin with Flavonoids from Abelmoschus manihot (L.) Medicus by CZE. Chromatographia2006 (64): 45.

10. Mandey JS. 2013. Genetic characterization, nutritional and phytochemicals potential of gedi leaves (Abelmoschus manihot L. Medik) growing in the North Sulawesi of Indonesia as a candidate of poultry feed. Research Report. Animal Husbandry Faculty, Sam Ratulangi University. Manado.

11. Mamahit L. P dan Soekamto N. H. 2010. Satu Senyawa Asam Organik Yang Diiolasi Dari Daun gedi (Abelmoschus manihot L. Medik) Asal Sulawesi Utara. Juruan Teknologi Pertanian. Fakulta Pertanian. Universitas Sam Ratulangi, Manado. J. Chem Prog, Vol 3 No.1.
12. Lin-lin W., Xin-bo Y., Zheng-ming H., He-zhi L., Guang-xia W. 2007. In vivo and in vitro antiviral activity of hyperoside extracted from Abelmoschus manihot (L) medic. Acta Pharmacol Sin28 (3):404-409.

13. Sarwar M, Attitalia IH, Abdollahi M . 2011. A review on the recent advances in pharmacological studies on medicinal plants; animal studies are done but clinical studies needs completing. Asian Journal of Animal and Veterinary Advances 6, 867-883.

14. Departemen Kesehatan Republik Indonesia \& Direktorat Jenderal Pengawasan Obat dan Makanan. 2000. Parameter Standar Umum Ekstrak Tumbuhan Obat. Bakti Husada. Jakarta.

15. Andersen, Ø.M. and Markham K.R. 2006. Flavonoids: Chemistry, Biochemistry, and Applications. Taylor \& Francis Group. USA. 2

16. Markham. K.R. 1988. Cara Mengindentifikasi Flavonoid, terjemahan K. Radmawinata. Penerbit ITB. Bandung. 1-117.

17. Mandey JS. 2013. Genetic characterization, nutritional and phytochemicals potential of gedi leaves (Abelmoschus manihot L. Medik) growing in the North Sulawesi of Indonesia as a candidate of poultry feed. Research Report. Animal Husbandry Faculty, Sam Ratulangi University. Manado.

18. Kusumawati, D. 2004. Bersahabat dengan Hewan Coba. Gajahmada University pers. Yogyakarta.

19. Agung, Nugroho. 2006. Hewan Percobaan Diabetes Melitus : Patologi dan Mekanisme Aksi Diabetagonik. Jurnal Fakultas Farmasi Universitas Gajah Mada. Yogyakarta.

20. Thongsom, M., Chunglok, W., Kuanchuea, R., Tongpong, J. 2013. Antioxidant and Hypoglycemic Effects of Tithonia diversifolia aqueous Leaves Extract Ind Alloxan- 
Induced Diabetic Mice. Advences In Environmental Biology Journal Vol. 7. No. 9. Hal 5, 9.

21. Wollenweber E, Dorr M, Muniappan R. Exudate Flavonoids in a Tropical Weed, Chromolaena odorata (L.) R. M. King et H. Robinson. Biochemical Sptematics and Ecology Vol. 23, 1995, 7 (8). Hal. 873-874

22. Widhafni, Septya. Bodhi, Widdhi, Suadewi, Sri. 2014. Uji Efektivitas Ekstrak Etanol Tunas Pisang Goroho (Musa acuminate L.) Terhadap Penurunan Kadar Gula Darah Tikus Putih Jantan Galur Wistar (Rattus norvegicus) Yang Diinduksi Sukrosa.
Jurnal Ilmiah Farmasi - UNSRAT Vol. 3 no. 2. Hal. 62-66

23. Lugasi, A., J. Hovari, K.V. Sagi and L. Biro. The Role of Antioxidant Phytonutrients In The Prevention of Disease. Acta Biologica Szegediensis. 2003; 47: Hal. 119-125

24. Ngozi, Igboh M., Ikewuchi, J.C., Ikewuchi C. C. 2009. Chemical Profile of Chromolaena odorata L. (King and Robinson) Leaves. Pakistan Journal of Nutrition 8 (5): 2009. Hal. 521-524

25. Malanggi, L., Sangi, M dan Pacdonk, J. 2012. Penuntun kandungan Tanin dan Uji Aktivitas Ekstrak Biji Buah Alpukat (Persea Americana Mill. Journal MIPA UNSTRAT. Hal 22-23 